AperTO - Archivio Istituzionale Open Access dell'Università di Torino

\title{
LIC-KOR Promoted Formation of Conjugate Dienes as Useful Building Blocks in Palladium-Catalyzed Syntheses
}

\section{This is the author's manuscript}

Original Citation:

\section{Availability:}

This version is available http://hdl.handle.net/2318/10324

since

Publisher:

Elsevier Science Limited:Oxford Fulfillment Center, PO Box 800, Kidlington Oxford OX5 1DX United

Published version:

DOI:10.1016/j.tet.2005.01.044

Terms of use:

Open Access

Anyone can freely access the full text of works made available as "Open Access". Works made available under a Creative Commons license can be used according to the terms and conditions of said license. Use of all other works requires consent of the right holder (author or publisher) if not exempted from copyright protection by the applicable law. 
Tetrahedron 61 (2005) 3429-3436

\title{
LIC-KOR promoted formation of conjugated dienes as useful building blocks for palladium-catalyzed syntheses
}

\author{
Annamaria Deagostino, ${ }^{\text {a }}$ Manuele Migliardi, ${ }^{a}$ Ernesto G. Occhiato, ${ }^{\text {a,b }}$ Cristina Prandi, ${ }^{\text {acc }}$ \\ Chiara Zavattaro ${ }^{\mathrm{a}}$ and Paolo Venturello ${ }^{\mathrm{a}, *}$ \\ à Dipartimento di Chimica Generale ed Organica Applicata dell'Università, Via Pietro Giuria, 7 I-10125 Torino, Italy \\ 'Dipartimento di Chimica Organica 'Ugo Schiff', and ICCOM, Università di Firenze, Via della Lastruccia, 13, \\ I-50019 Sesto Fiorentino, Italy \\ ${ }^{\mathrm{c}}$ Dipartimento di Scienze Ambiente e Vita, Università del Piemonte Orientale, Spalto Marengo, 33, I-15100 Alessandria, Italy
}

Received 24 September 2004; revised 11 November 2004; accepted 6 January 2005

Available online 2 February 2005

\begin{abstract}
It is demonstrated that $\alpha, \beta$-unsaturated acetals can be considered a synthetic tool for transforming carbonyl derivatives into cheap and easily accessible starting materials for the construction of various and more complex structures. The lithium-potassium mixed superbase LIC-KOR induces a conjugate elimination reaction that converts $\alpha, \beta$-unsaturated acetals into $1 E$-1-alkoxybuta-1,3-dienes. These derivatives can be readily metalated in situ and functionalized by reaction with electrophiles. The results can be grouped in two sections: (1) the palladium-catalyzed cross-coupling reaction between alkoxydienylboronates and tetralone- or isochromanone-derived vinyl triflates; (2) the regio- and stereoselective cross coupling reaction with aryl derivatives in the presence of a palladium catalyst (Heck conditions).

(C) 2005 Elsevier Ltd. All rights reserved.
\end{abstract}

\section{Introduction}

A few years ago, we reported that in the presence of Schlosser's superbase LIC-KOR ${ }^{1}$ (LIC: butyllithium, KOR: potassium tert-butoxide), $\alpha, \beta$-unsaturated acetals selectively yield 1-alkoxybuta-1,3-dienes. ${ }^{2}$ The product derives from a stereoselective conjugate elimination that is initiated by the metalation reaction at the $\gamma$-allylic position of the unsaturated substrate. Moreover, butadienyl derivatives can be further functionalized at their $\alpha$-position by conducting the former elimination reaction in the presence of at least two equivalents of the LIC-KOR base: the excess reagent selectively deprotonates the elimination product at the 1-alkenyl site, giving a nucleophile that can be quenched with various electrophiles, yielding substitution or addition products. ${ }^{3}$ By resorting to this procedure, we have described different functionalized unsaturated systems. ${ }^{4}$ More recently, the reactivity of $\alpha$-metalated alkoxydienes in the presence of trialkylboranes ${ }^{5}$ and trialkylborates ${ }^{6}$ as electrophiles has also been described (Scheme 1). The arylation of $\alpha, \beta$-unsaturated carbonyl compounds by an Heck reaction has also been reported. ${ }^{\text {? }}$

In this paper we provide the details of our work on two

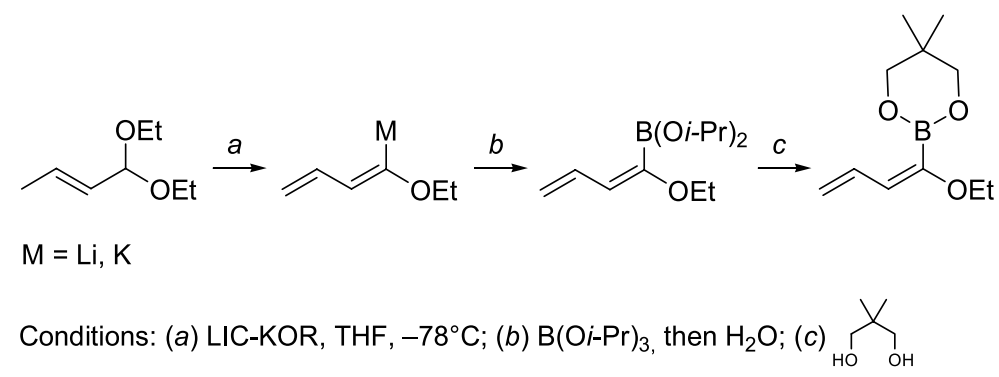

Scheme 1. Synthesis of trialkylborates starting from $\alpha, \beta$-unsaturated acetals, in the presence of LIC-KOR superbase.

Keywords: Unsaturated acetals; Mixed superbases; Pd-catalyzed reactions; Suzuki reaction; Heck reaction; Nazarov reaction

* Corresponding author. Fax: +390112367646; e-mail: paolo.venturello@unito.it 


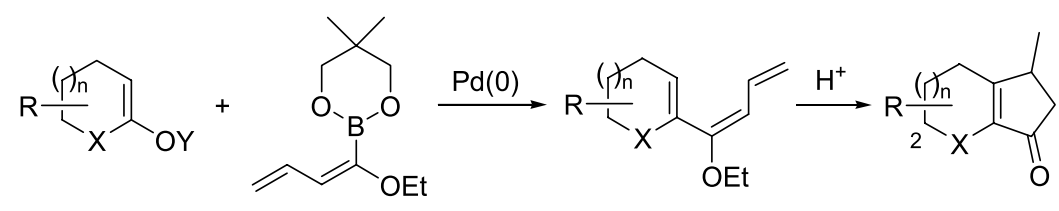

$$
\begin{aligned}
\mathrm{X} & =\mathrm{N}-\mathrm{Cbz}, N-\mathrm{Ts}, \mathrm{O} \\
\mathrm{Y} & =\mathrm{Tf}, \mathrm{P}(\mathrm{O})(\mathrm{OPh})_{2} \\
\mathrm{n} & =0,1,2
\end{aligned}
$$

Scheme 2. Pd-catalyzed cross-coupling reaction of lactam- and lactone derived triflates or phosphates with 2-(1-ethoxybuta-1,3-dienyl)-5,5-dimethyl-[1,3,2]dioxaborinane, and subsequent Amberlyst- $15^{\circledR}$ catalyzed cyclization.

different uses of alkoxydienyl derivatives in synthesis: (1) the Pd-catalyzed cross-coupling reaction with tetralone- or isochromanone-derived vinyl triflates or phosphates, and (2) the Heck coupling with diazonium salts.

\subsection{Pd-catalyzed cross-coupling reaction with lactam- and lactone-derived vinyl triflates or phosphates}

We have recently found that conjugated ethoxytrienes obtained by the Pd-catalyzed cross-coupling reaction of lactam- and lactone- derived triflates or phosphates with ethoxydienylboronates (Scheme 2) undergo cyclization in the presence of the acidic resin Amberlyst- $15^{\circledR}$ to give byciclic fused [3.3.0], [4.3.0], and [5.3.0] systems. ${ }^{8} \mathrm{~A}$ Nazarov-type electrocyclization can explain the cyclization reaction. ${ }^{9}$ This process has been extended here to the synthesis of tricarbocyclic derivatives by exploiting commercially available $\alpha$-tetralones with different patterns of substitution.

Commercially available $\alpha$-tetralones 1a-c (Scheme 3 ) were converted into the corresponding triflates $\mathbf{2} \mathbf{a}-\mathbf{c}$ by treatment with LHMDS at $-78^{\circ} \mathrm{C}$ and by trapping the enolates with $N$-phenyl triflimide. The triflates thus obtained proved to be stable enough to be purified by flash chromatography and successively coupled with 2-(1-ethoxybuta-1,3-dienyl)-5,5,dimethyl-[1,3,2]-dioxaborinane. ${ }^{6}$ The reaction was performed with $\left(\mathrm{Ph}_{3} \mathrm{P}\right)_{2} \mathrm{PdCl}_{2}(5 \%)$ as a catalyst in THF and $2 \mathrm{M} \mathrm{K}_{2} \mathrm{CO}_{3}$ as a base at room temperature and was complete in $1 \mathrm{~h}$. Chromatography of the crude reaction mixture afforded pure ethoxytrienes 3a-c in good yields that were used for the subsequent intramolecular cyclization. In our previous studies we have already shown that hydrolysis conditions strongly affect the reaction outcome. As a matter of fact the mechanism could be driven towards the synthesis of $\alpha, \beta$-unsaturated ketone (5) or towards the Nazarov adducts (4) by choosing the appropriate acidic catalyst and solvent. In $0.02 \mathrm{M} \mathrm{HCl} \mathrm{MeOH}-\mathrm{H}_{2} \mathrm{O}$ as a solvent, the open chain ketone was recovered as the main product and could be successively transformed into the Nazarov adduct by treatment with pure TFA at room temperature, while the acidic sulfonic resin Amberlyst-15 ${ }^{\circledR}$ promoted the electrocyclic process. Ethoxytrienes $3 \mathbf{a}-\mathbf{c}$ have been hydrolyzed under inert atmosphere using Amberlyst- $15^{\circledR}$ as a catalyst and anhydrous $\mathrm{CH}_{2} \mathrm{Cl}_{2}$ as a solvent. In all examples products $\mathbf{4 a}-\mathbf{c}$ were obtained in good yields, while open chain ketones 5a-c were merely obtained in traces. In particular, 4b was recovered as a 1:1 mixture of cis and trans diastereomers. We were not surprised to find a lack of diastereocontrol in the electrocyclization of $\mathbf{3 b}$. In our studies on the torquoselectivity of the Nazarov reaction performed on ethoxytrienes in which one double bond is embedded in a heterocyclic structure, we have found that, while substituents in 2- or 4-position of the heterocyclic moiety could affect the diastereoselection, a substituent at position 3 exerted a low remote stereocontrol. ${ }^{8}$ In compound 3b the methyl group in position 3 is too far from the reacting centers to affect the sense of electrocyclic conrotation so that the two faces of the endocyclic double bond are not differentiated and both modes of conrotation are thus possible. $^{10}$

The here described synthetic sequence could be applicable to the construction of new derivatives structurally connected<smiles>[R]c1cccc2c1C(=O)CCC2[R]</smiles>

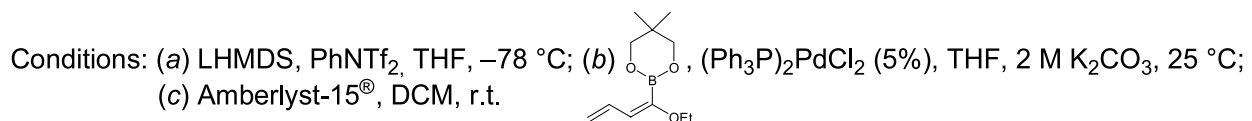

Scheme 3. Pd-catalyzed cross-coupling reaction of $\alpha$-tetralones derived triflates with 2-(1-ethoxybuta-1,3-dienyl)-5,5,-dimethyl-[1,3,2]-dioxaborinane, and subsequent Amberlyst-15 ${ }^{\circledR}$ catalyzed cyclization. 
to some attractive natural products, in particular to biologically active substances endowed with a ring system in which a substituted aromatic nucleus is fused to a hydrindane framework, ${ }^{11}$ as in the core of the hamigerans (Fig. 1). Hamigerans are a small group natural products that were isolated from the marine sponge Hamigera tarangaensis. ${ }^{12}$ The biological activity profile of hamigerans is quite interesting: in particular, for hamigeran B3 has been found a $100 \%$ in vitro inhibition against both herpes and polio viruses. ${ }^{13}$ The absolute configuration of hamigeran A1 has been determined by X-ray crystallographic analysis. ${ }^{14}$ Because of their biological properties and novel structural features, the synthesis of hamigerans represents an important synthetic target. ${ }^{15}$ For the synthesis of an analogue of hamigerans containing an heteroatom in the [4.3.0] bicyclic moiety, the same synthetic sequence was applied to the aromatic lactone 3-isochroman-2-one 1d (Scheme 4). Triflate 2d was coupled with 2-(1-ethoxybuta-1,3-dienyl)5,5,-dimethyl-[1,3,2]-dioxaborinane under the usual conditions $\left[\left(\mathrm{Ph}_{3} \mathrm{P}\right)_{2} \mathrm{PdCl}_{2}(5 \%), \mathrm{THF}, 2 \mathrm{M} \mathrm{K} \mathrm{K}_{2} \mathrm{CO}_{3}, 25^{\circ} \mathrm{C}\right]$ giving triene 3d. The hydrolysis of 3d with Amberlyst- $15^{\circledR}$ afforded cyclic ketone $\mathbf{4 d}$ along with the open chain isomer $\mathbf{5 d}$ that, in this case, was unexpectedly isolated in significant yield. However, it could be easily converted into $4 \mathbf{d}$ by treatment with pure TFA at $25^{\circ} \mathrm{C}$.

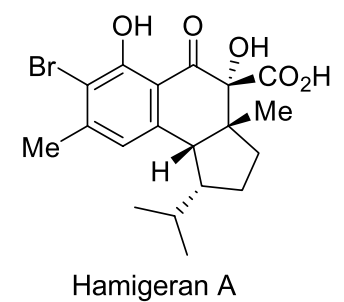

Figure 1.

\subsection{Heck coupling with diazonium salts}

Substituted dienes and other unsaturated structures are very attractive as precursors of dyes, UV screens, and drugs. ${ }^{16}$ Although arylation of two-carbon vinyl fragments might sometimes result in scarcely regioselective reactions, ${ }^{17,18}$ highly regioselective $\alpha$-arylation and $\alpha$-vinylation procedures have been reported under specific experimental conditions. ${ }^{19}$ In particular, $100 \%$ regioselective $\alpha$-functionalization of vinyl ethers can be achieved by favoring the coordination of the Pd complex to the carboncarbon double bond via dissociation of the anion ligand. Such a mechanism can be promoted by using triflate as a leaving group or adding a sequestering agent of halide anions. ${ }^{20}$ Otherwise, a mixture of isomers is obtained when the coordination-insertion process proceeds via dissociation of one neutral ligand. Moreover, regioselective $\beta$-arylation of vinyl ethers has been achieved when the olefinic substrate contains groups that control the palladium catalyzed reaction through chelation. Such a procedure has been reported as a useful access to arylethylamines or arylacetic acids of significant pharmaceutical value. ${ }^{21}$ On the other hand, the Pd-catalyzed arylation of conjugate dienes would be expected to produce arylated dienes. However, some differences and perhaps complications could be expected since $\pi$-allylic palladium species are involved in the reactions. Particularly stable $\pi$-allylic complexes in the presence of tertiary amines are formed, while the use of secondary amines leads to mixtures of polyenes and allylic amines. $^{22}$ Thus, low yields and/or low selectivity are encountered when the diene does not have a carbonyl or phenyl group and the synthesis of linear conjugated polyenes remains to be improved. Recently we reported a regioselective $\gamma$-arylation of $\alpha, \beta$-unsaturated carbonyl compounds from aryl iodides and alkoxydienes by an Heck reaction. ${ }^{7}$ We observed the stereoselective formation of $\gamma$-arylated $\alpha, \beta$-unsaturated acetals in good yields working in DMSO at $80^{\circ} \mathrm{C}$, and using $\mathrm{K}_{2} \mathrm{CO}_{3}$ as a base and $\mathrm{Pd}(\mathrm{OAc})_{2}$ as a catalyst (Scheme 5(A)). A possible mechanism has been also suggested: first, the arylpalladium intermediate adds to the terminal double bond of the diene, then this intermediate arranges to the $\pi$-allylic complex and an iodide ion-acetate ligand exchange takes place. Finally, attack of the hydroxy group upon the complex displaces the palladium complex and gives the cyclic acetal.

In this paper we wish to report the results obtained studying the Pd-catalyzed cross coupling reaction of 1-alkoxy-1,3butadienes with arendiazonium salts. The Heck reaction with these substrates is mild and fast. Moreover, the use of these compounds is synthetically more convenient than the use of aryl halides, since many of them, especially iodides, are prepared from diazonium salts. Interestingly, no
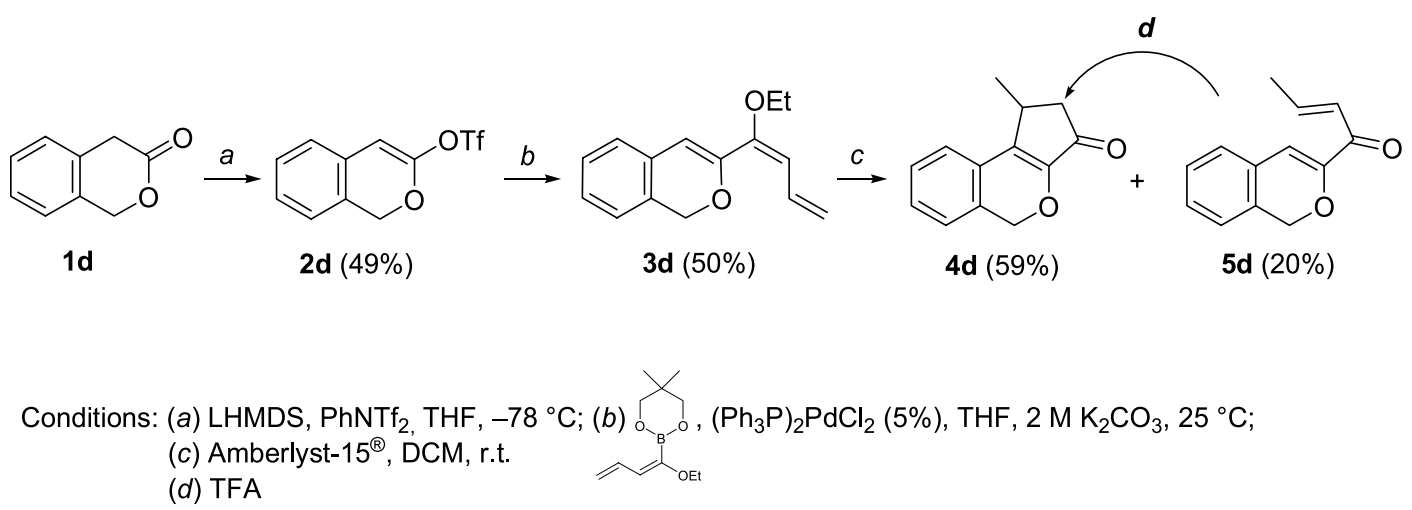

Scheme 4. Pd-catalyzed cross-coupling reaction of 3-isochroman-2-one derived triflate with 2-(1-ethoxybuta-1,3-dienyl)-5,5,-dimethyl-[1,3,2]-dioxaborinane, and subsequent Amberlyst- $15^{\circledR}$ catalyzed cyclization. 


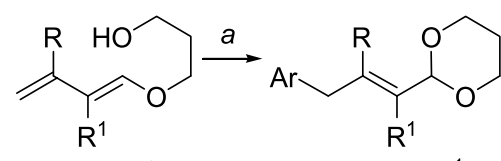

$$
\begin{array}{ll}
\text { 6a: } \mathrm{R}=\mathrm{R}^{1}=\mathrm{H} & \text { 7a: } \mathrm{R}=\mathrm{H}, \mathrm{R}^{1}=\mathrm{H}, \mathrm{Ar}=p-\mathrm{MeOC}_{6} \mathrm{H}_{4}(30 \%) \\
\text { 6b: } \mathrm{R}=\mathrm{Me} ; \mathrm{R}^{1}=\mathrm{H} & \text { 7b: } \mathrm{R}=\mathrm{H}, \mathrm{R}^{1}=\mathrm{H}, \mathrm{Ar}=m-\mathrm{MeOC}_{6} \mathrm{H}_{4}(37 \%) \\
\text { 6c: } \mathrm{R}=\mathrm{H} ; \mathrm{R}^{1}=\mathrm{Me} & \text { 7c: } \mathrm{R}=\mathrm{H}, \mathrm{R}^{1}=\mathrm{H}, \mathrm{Ar}=p-\mathrm{IC}_{6} \mathrm{H}_{4}(34 \%) \\
& \text { 7d: } \mathrm{R}=\mathrm{H}, \mathrm{R}^{1}=\mathrm{H}, \mathrm{Ar}=p-\mathrm{CIC}_{6} \mathrm{H}_{4}(34 \%) \\
& \text { 7e: } \mathrm{R}=\mathrm{Me}, \mathrm{R}^{1}=\mathrm{H}, \mathrm{Ar}=p-\mathrm{IC}_{6} \mathrm{H}_{4}(27 \%) \\
\text { 7f: } \mathrm{R}=\mathrm{Me}, \mathrm{R}^{1}=\mathrm{H}, \mathrm{Ar}=p-\mathrm{ClC}_{6} \mathrm{H}_{4}(25 \%) \\
\text { 7g: } \mathrm{R}=\mathrm{H}, \mathrm{R}^{1}=\mathrm{Me}, \mathrm{Ar}=p-\mathrm{IC}_{6} \mathrm{H}_{4}(30 \%)
\end{array}
$$

\section{A: (a) Arl, $\mathrm{K}_{2} \mathrm{CO}_{3}, 80^{\circ} \mathrm{C}, \mathrm{AcO}_{2} \mathrm{Pd}$, DMSO \\ B: (a) $\mathrm{ArN}_{2}{ }^{+} \mathrm{BF}_{4}^{-}, \mathrm{AcONa}, 25^{\circ} \mathrm{C}, \mathrm{Pd}(\mathrm{OAc})_{2}, \mathrm{MeCN}$}

Scheme 5. Heck reaction on 1-(3-hydropropoxy)buta-1,3-dienes.

difference in reactivity in relation to the electronic nature of the diazonium compound is observed. ${ }^{23}$ Moreover it seems that for this type of Heck reaction, contrary to the reactions of aryl chlorides or bromides, the insertion of the palladium catalyst is not the rate determining step. ${ }^{24}$ Unfortunately, the process is rather inefficient as the loading of Pd precatalyst required is usually no less than $1-2 \mathrm{~mol} \%$. Most probably this is associated with an inefficient preactivation of the catalyst.

The use of bases and strongly coordinating ligands in reactions with arendiazonium salts is usually detrimental as a consequence of dediazotation: ${ }^{25}$ unfortunately, basic conditions are required since the starting alkoxydienes and products are acid sensitive and the formation of acids caused by $\beta$-H-elimination can be problematic. ${ }^{26}$ In fact, some tests carried out without addition of base did not give the expected arylated compound in appreciable amount.

The results of the cross coupling reaction are reported in Scheme 5(B). These data have been obtained working in anhydrous MeCN (alcoholic solvents turned out inadequate) at room temperature in the presence of NaOAc as a base and of $\mathrm{Pd}(\mathrm{OAc})_{2}$ as a catalyst.

First of all, we focused our attention on halo-substituted diazonium salts because of the interest towards differential $\mathrm{Pd}$-catalyzed reaction in the synthesis of unsymmetrical substituted teraryls and oligoarylenesvinylenes considering their medicinal and NLO properties. ${ }^{27}$

The reactions are regio- and stereoselective, and the aryl group adds, as expected, to the unsubstituted $\mathrm{CH}_{2}$ site of the conjugate system. Unfortunately, the coupling yields are modest: probably they are affected by the stability of whether the diazonium salts or the dienes under the reaction conditions.

When the cross-coupling reaction was carried out on $(E)-4-$ ethoxyocta-1,3-diene $\mathbf{6 d}$ the corresponding $(2 E)$ - $\gamma$-arylated $\alpha, \beta$-unsaturated ketone $\mathbf{7 h}$ was recovered (Scheme 6 ). The formation of the conjugate ketone can be most likely attributed to the presence of water molecules that may be present in the diazonium salt or in the base.

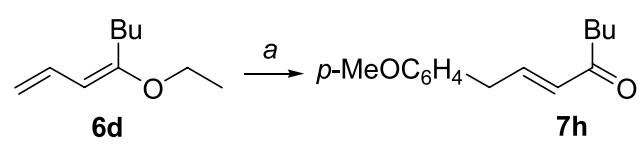

Conditions: (a) $p-\mathrm{MeOC}_{6} \mathrm{H}_{4} \mathrm{~N}_{2}{ }^{+} \mathrm{BF}_{4}^{-}$, AcONa, r.t., $\mathrm{Pd}(\mathrm{OAc})_{2}, \mathrm{MeCN}$

Scheme 6. Heck reaction on (E)-4-ethoxyocta-1,3-diene.

\section{Conclusions}

In summary, we have developed new synthetic routes that allow the acetal group of $\alpha, \beta$-unsaturated acetals to be considered not simply a protective function but also a useful synthetic tool. In particular, we have shown that Suzuki coupling of ethoxydienylboronates with vinyl triflates or phosphates derived from aromatic ketones or lactones is a tactically suitable strategy for the synthesis of cyclopentafused polycyclic systems that are present in many natural products. Moreover, when 1-alkoxybuta-1,3-dienes cross couple under Heck conditions with arendiazonium derivatives, the final outcome of the process formally corresponds to the direct $\gamma$-arylation of starting $\alpha, \beta$-unsaturated acetals.

\section{Experimental}

\subsection{General}

Flasks and all equipments used for the generation and reaction of moisture-sensitive compounds are flame dried under Argon. Anhydrous $\mathrm{CH}_{3} \mathrm{CN}$ was purchased by Fluka. All aromatic substrates, palladium(II) acetate, palladium bistriphenylphosphinobichloride, NaOAc and $\mathrm{K}_{2} \mathrm{CO}_{3}$ are commercially available and are used as received. All the acetals and ethoxydienes were prepared as previously described. ${ }^{4}$ The arenediazonium tetrafluoborates were prepared from commercial aromatic amines according to reported procedures. ${ }^{28}$ Purification of products was carried out by preparative column chromatography on Merck Silica gel 60 with light petroleum ether (distillation range 40 $\left.60{ }^{\circ} \mathrm{C}\right)-\mathrm{Et}_{2} \mathrm{O}$ as eluent. ${ }^{1} \mathrm{H}$ NMR spectra were recorded at 200 or $400 \mathrm{MHz}$ in $\mathrm{CDCl}_{3}$, using TMS as internal standard. Coupling constants $(J)$ are given in $\mathrm{Hz}$ and coupling patterns are described by abbreviations: s (singlet), d (doublet), $\mathrm{t}$ (triplet), q (quartet), br s (broad singlet). ${ }^{13} \mathrm{C} \mathrm{NMR} \mathrm{spectra}$ are recorded at 50 and $100.4 \mathrm{MHz}$ in $\mathrm{CDCl}_{3}$, and chemical shifts are determined relative to the residual solvent peak (77.36). GC-MS spectra are obtained on a mass selective detector HP 5970 B instrument operating at an ionizing voltage of $70 \mathrm{eV}$ connected to a HP $5890 \mathrm{GC}$, cross linked methyl silicone capillary column $(25 \mathrm{~m} \times 0.2 \mathrm{~mm} \times$ $0.33 \mu \mathrm{m}$ film thickness).

3.1.1. Trifluoromethanesulfonic acid 3,4-dihydronaphthalen-1-yl ester (2a). Typical procedure. To a solution of KHMDS ( $8 \mathrm{~mL}$ of a $0.5 \mathrm{M}$ solution in toluene, $4 \mathrm{mmol})$ in THF $(12 \mathrm{~mL})$, cooled at $-78^{\circ} \mathrm{C}$ and under nitrogen atmosphere, was added a solution of 3,4-dihydro$2 H$-naphthalen-1-one (440 mg, $3 \mathrm{mmol}$ ) in THF (4 mL) and the resulting mixture was stirred for $1.5 \mathrm{~h}$. Afterward a solution of $\mathrm{PhNTf}_{2}(964 \mathrm{mg}, 2.7 \mathrm{mmol})$ in THF (2 mL) was quickly added, leaving under stirring for $1 \mathrm{~h}$ at $-78^{\circ} \mathrm{C}$ 
before allowing the temperature to rise to $0{ }^{\circ} \mathrm{C}$. Then, a $10 \%$ $\mathrm{NaOH}$ solution $(20 \mathrm{~mL})$ was added, the mixture was extracted with $\mathrm{Et}_{2} \mathrm{O}(3 \times 20 \mathrm{~mL})$, washed with $\mathrm{H}_{2} \mathrm{O}(2 \times$ $10 \mathrm{~mL})$, and dried $\left(\mathrm{K}_{2} \mathrm{CO}_{3}\right)$. After filtration and evaporation of the solvent, crude vinyl triflate $\mathbf{1}$ was obtained as a yellowish oil and purified by flash chromatography (petroleum ether: $\mathrm{Et}_{2} \mathrm{O}$ 4:1, $610 \mathrm{mg}, 73 \%$ ): $200 \mathrm{MHz}{ }^{1} \mathrm{H}$ NMR (200 MHz, $\left.\mathrm{CDCl}_{3}\right): \delta 7.3(\mathrm{~m}, 4 \mathrm{H}), 6.05(\mathrm{t}, J=2.9 \mathrm{~Hz}$, $1 \mathrm{H}), 2.90(\mathrm{t}, J=6.5 \mathrm{~Hz}, 2 \mathrm{H}), 2.5(\mathrm{~m}, 2 \mathrm{H})$.

3.1.2. Trifluoromethanesulfonic acid 4-methyl-3,4dihydro-naphthalen-1-yl ester (2b). Flash chromatography $\left(\mathrm{Et}_{2} \mathrm{O}-\right.$ petroleum ether $\left.1: 4,0.5 \% \mathrm{Et}_{3} \mathrm{~N}\right)$ gave pure 2b $\left(531 \mathrm{mg}, 61 \%, R_{\mathrm{f}} 0.75\right)$ as a yellow oil. ${ }^{1} \mathrm{H}$ NMR $\left(200 \mathrm{MHz} \mathrm{CDCl}_{3}\right): \delta 7.2(\mathrm{~m}, 4 \mathrm{H}), 6.01(\mathrm{t}, J=2.9 \mathrm{~Hz}, 1 \mathrm{H})$, 3.01 (hex, $J=6.5 \mathrm{~Hz}, 1 \mathrm{H}$ ), 2.75 (ddd, $J=13.0,6.5,2.9 \mathrm{~Hz}$, $1 \mathrm{H}), 2.29(\mathrm{dd}, J=13.0,2.9 \mathrm{~Hz}, 1 \mathrm{H}), 1.35(\mathrm{~d}, J=6.5 \mathrm{~Hz}$, $3 \mathrm{H})$.

3.1.3. Trifluoromethanesulfonic acid 5-methoxy-3,4dihydro-naphthalen-1-yl ester (2c). Flash chromatography $\left(\mathrm{Et}_{2} \mathrm{O}\right.$-petroleum ether 1:4, $\left.0.5 \% \mathrm{Et}_{3} \mathrm{~N}\right)$ gave pure 2c $\left(678 \mathrm{mg}, 73 \%, R_{\mathrm{f}} 0.76\right)$ as a yellow oil. ${ }^{1} \mathrm{H}$ NMR $\left(200 \mathrm{MHz} \mathrm{CDCl}_{3}\right): \delta 7.33(\mathrm{t}, J=5.9 \mathrm{~Hz}, 1 \mathrm{H}), 7.18(\mathrm{~d}, J=$ $5.9 \mathrm{~Hz}, 1 \mathrm{H}), 6.97(\mathrm{~d}, J=5.9 \mathrm{~Hz}, 1 \mathrm{H}), 6.04(\mathrm{t}, J=2.9 \mathrm{~Hz}$, $1 \mathrm{H}), 3.95(\mathrm{~s}, 3 \mathrm{H}), 2.95(\mathrm{t}, J=5.5 \mathrm{~Hz}, 2 \mathrm{H}), 2.65(\mathrm{~m}, 1 \mathrm{H}), 2.5$ $(\mathrm{m}, 1 \mathrm{H})$.

3.1.4. Trifluoromethanesulfonic acid $1 \mathrm{H}$-isochromen-3yl ester (2d). Flash chromatography $\left(\mathrm{Et}_{2} \mathrm{O}-\right.$ petroleum ether $\left.3: 7,0.5 \% \mathrm{Et}_{3} \mathrm{~N}\right)$ gave pure $2 \mathrm{~d}\left(414 \mathrm{mg}, 49 \%, R_{\mathrm{f}} 0.74\right)$ as a yellow oil. ${ }^{1} \mathrm{H}$ NMR $\left(200 \mathrm{MHz} \mathrm{CDCl}_{3}\right): \delta 7.2(\mathrm{~m}, 4 \mathrm{H}), 5.81$ (s, 1H), 5.37 (s, 2H).

\subsubsection{E-4-(1-Ethoxy-buta-1,3-dienyl)-1,2-dihydro-} naphthalene (3a). Typical procedure. To a solution of crude $2 \mathbf{a}(417 \mathrm{mg}, 1.5 \mathrm{mmol})$ in THF (4 mL) were added, under a nitrogen atmosphere, $\left(\mathrm{Ph}_{3} \mathrm{P}\right)_{2} \mathrm{PdCl}_{2}(57 \mathrm{mg}$, $0.075 \mathrm{mmol}), 2$-(1-ethoxybuta-1,3-dienyl)-5,5,-dimethyl$[1,3,2]$-dioxaborinane $(315 \mathrm{mg}, 1.5 \mathrm{mmol})$, and a $2 \mathrm{M}$ aqueous $\mathrm{K}_{2} \mathrm{CO}_{3}$ solution $(1.5 \mathrm{~mL})$. The mixture was stirred for $2.5 \mathrm{~h}$ at $25^{\circ} \mathrm{C} \cdot \mathrm{H}_{2} \mathrm{O}(10 \mathrm{~mL})$ was then added, the mixture extracted with diethyl ether $(3 \times 20 \mathrm{~mL})$ and dried $\left(\mathrm{Na}_{2} \mathrm{SO}_{4}\right)$. Evaporation of the solvent afforded a yellow oil that was purified by flash chromatography (petroleum ether$\left.\mathrm{Et}_{2} \mathrm{O} 4: 1,0.5 \% \mathrm{Et}_{3} \mathrm{~N}, R_{\mathrm{f}} 0.7\right)$ to give $4 \mathbf{a}(180 \mathrm{mg}, 53 \%)$ as a colorless oil. ${ }^{1} \mathrm{H}$ NMR $\left(200 \mathrm{MHz}, \mathrm{CDCl}_{3}\right): \delta 7.09(\mathrm{~s}, 4 \mathrm{H})$, $6.38(\mathrm{dt}, J=15.0,10.5 \mathrm{~Hz}, 1 \mathrm{H}), 6.10(\mathrm{t}, J=2.9 \mathrm{~Hz}, 1 \mathrm{H})$, $5.65(\mathrm{~d}, J=10.5 \mathrm{~Hz}, 1 \mathrm{H}), 5.06(\mathrm{dd}, J=15.0,1.8 \mathrm{~Hz}, 1 \mathrm{H})$, $4.81(\mathrm{dd}, J=10.5,1.8 \mathrm{~Hz}, 1 \mathrm{H}), 3.84(\mathrm{q}, J=7.5 \mathrm{~Hz}, 2 \mathrm{H})$, $2.82(\mathrm{t}, J=6.5 \mathrm{~Hz}, 2 \mathrm{H}), 2.42(\mathrm{~m}, 2 \mathrm{H}), 1.27(\mathrm{t}, J=7.5 \mathrm{~Hz}$, $3 \mathrm{H}) ;{ }^{13} \mathrm{C} \mathrm{NMR}\left(50 \mathrm{MHz}, \mathrm{CDCl}_{3}\right): \delta 152.6,143.6,137.5$, $136.4,135.4,134.0,133.1,130.4,129.4,128.0,125.8$, 119.2, 69.8, 42.6, 29.3, 19.5; MS m/z $226\left(\mathrm{M}^{+}, 100\right), 197$ (35), 181 (37), 115 (23). Anal. Calcd for $\mathrm{C}_{16} \mathrm{H}_{18} \mathrm{O}$ : C, 84.91; H, 8.02. Found: C, 84.79; H, 8.72.

3.1.6. 4-(1-Ethoxy-buta-1,3-dienyl)-1-methyl-1,2dihydro-naphthalene (3b). Flash chromatography $\left(\mathrm{Et}_{2} \mathrm{O}-\right.$ petroleum ether $\left.1: 9,0.5 \% \mathrm{Et}_{3} \mathrm{~N}\right)$ gave pure $\mathbf{3 b}(165 \mathrm{mg}$, $\left.69 \%, R_{\mathrm{f}}=0.85\right)$ as a colorless oil. ${ }^{1} \mathrm{H}$ NMR $\left(\mathrm{CDCl}_{3}\right.$, $200 \mathrm{MHz}): \delta 7.3(\mathrm{~m}, 4 \mathrm{H}), 6.30(\mathrm{dt}, J=15.0,10.5 \mathrm{~Hz}, 1 \mathrm{H})$, $6.06(\mathrm{t}, J=2.9 \mathrm{~Hz}, 1 \mathrm{H}), 5.66(\mathrm{~d}, J=10.5 \mathrm{~Hz}, 1 \mathrm{H}), 5.06(\mathrm{dd}$,
$J=15.0,1.8 \mathrm{~Hz}, 1 \mathrm{H}), 4.81(\mathrm{dd}, J=10.5,1.8 \mathrm{~Hz}, 1 \mathrm{H}), 3.87$ (q, $J=7.5 \mathrm{~Hz}, 2 \mathrm{H}), 2.97$ (hex, $J=6.5 \mathrm{~Hz}, 1 \mathrm{H}$ ), 2.45 (ddd, $J=15.0,6.5,2.9 \mathrm{~Hz}, 1 \mathrm{H}), 2.20(\mathrm{dd}, J=15.0,2.9 \mathrm{~Hz}, 1 \mathrm{H})$, $1.28(\mathrm{~m}, 6 \mathrm{H}) ;{ }^{13} \mathrm{C} \mathrm{NMR}\left(\mathrm{CDCl}_{3}, 100 \mathrm{MHz}\right) \delta 160.39$, $143.20,130.83,130.26,130.13,129.65,129.01,128.90$, $128.30,127.55,113.92,108.06,65.82,34.08,33.85,22.77$, 17.93; MS m/z $240\left(\mathrm{M}^{+}, 100\right), 211$ (16), 193 (13), 129 (15). Anal. Calcd for $\mathrm{C}_{17} \mathrm{H}_{20} \mathrm{O}$ : C, 84.96; H, 8.39. Found: C, 84.12; H, 8.09.

3.1.7. 4-(1-Ethoxy-buta-1,3-dienyl)-8-methoxy-1,2dihydro-naphthalene $(3 \mathrm{c})$. Flash chromatography $\left(\mathrm{Et}_{2} \mathrm{O}-\right.$ petroleum ether $\left.2: 8,0.5 \% \mathrm{Et}_{3} \mathrm{~N}\right)$ gave pure $3 \mathrm{c}(154 \mathrm{mg}$, $\left.60 \%, R_{\mathrm{f}}=0.80\right)$ as a colorless oil. ${ }^{1} \mathrm{H} \mathrm{NMR}\left(\mathrm{CDCl}_{3}\right.$, $200 \mathrm{MHz}): \delta 7.01(\mathrm{t}, J=5.5 \mathrm{~Hz}, 1 \mathrm{H}), 6.96(\mathrm{~d}, J=5.5 \mathrm{~Hz}$, $1 \mathrm{H}), 6.85(\mathrm{~d}, J=5.5 \mathrm{~Hz}, 1 \mathrm{H}), 6.72(\mathrm{dt}, J=15.0,10.5 \mathrm{~Hz}$, $1 \mathrm{H}), 6.11(\mathrm{t}, J=3.0 \mathrm{~Hz}, 1 \mathrm{H}), 5.66(\mathrm{~d}, J=10.5 \mathrm{~Hz}, 1 \mathrm{H}), 5.09$ $(\mathrm{dd}, J=15.0,1.8 \mathrm{~Hz}, 1 \mathrm{H}), 4.85(\mathrm{dd}, J=10.5,1.8 \mathrm{~Hz}, 1 \mathrm{H})$, $3.86(\mathrm{q}, J=7.5 \mathrm{~Hz}, 2 \mathrm{H}), 3.84(\mathrm{~s}, 3 \mathrm{H}), 2.83(\mathrm{t}, J=5.2 \mathrm{~Hz}$, $2 \mathrm{H}), 2.36(\mathrm{~m}, 2 \mathrm{H}), 1.33(\mathrm{t}, J=7.5 \mathrm{~Hz}, 3 \mathrm{H}) ;{ }^{13} \mathrm{C} \mathrm{NMR}$ $\left(\mathrm{CDCl}_{3}, 100 \mathrm{MHz}\right) \delta 160.65,158.66,136.84,136.16$, $134.52,129.17,127.52,120.26,113.82,112.52,107.78$, 103.31, 67.02, 58.18, 25.14, 21.99, 18.23; MS m/z $256\left(\mathrm{M}^{+}\right.$, 100), 225 (22), 211 (32), 199 (20), 165 (23). Anal. Calcd for $\mathrm{C}_{17} \mathrm{H}_{20} \mathrm{O}_{2}$ : C, 79.65; H, 7.86. Found: C, 79.21; H, 7.19.

3.1.8. 3-(1-Ethoxy-buta-1,3-dienyl)-1H-isochromene (3d). Flash chromatography $\left(\mathrm{Et}_{2} \mathrm{O}\right.$-petroleum ether 2:8, $\left.0.5 \% \mathrm{Et}_{3} \mathrm{~N}\right)$ gave pure $3 d\left(115 \mathrm{mg}, 50 \%, R_{\mathrm{f}}=0.85\right)$ as a colorless oil. ${ }^{1} \mathrm{H} \mathrm{NMR}\left(\mathrm{CDCl}_{3}, 200 \mathrm{MHz}\right): \delta 7.2(\mathrm{~m}, 5 \mathrm{H})$, $6.34(\mathrm{~s}, 1 \mathrm{H}), 5.68(\mathrm{~d}, J=10.5 \mathrm{~Hz}, 1 \mathrm{H}), 5.14(\mathrm{~s}, 2 \mathrm{H}), 5.10$ $(\mathrm{dd}, J=15.0,1.8 \mathrm{~Hz}, 1 \mathrm{H}), 4.95(\mathrm{dd}, J=10.5,1.8 \mathrm{~Hz}, 1 \mathrm{H})$, $3.88(\mathrm{q}, J=7.5 \mathrm{~Hz}, 2 \mathrm{H}), 1.33(\mathrm{t}, J=7.5 \mathrm{~Hz}, 3 \mathrm{H}) ;{ }^{13} \mathrm{C} \mathrm{NMR}$ $\left(\mathrm{CDCl}_{3}, 100 \mathrm{MHz}\right) \delta 156.58,153.59,135.73,133.70$, $130.80,129.58,127.91,126.63,126.35,117.26,111.42$, 108.59, 71.12, 66.80, 18.23; MS m/z $228\left(\mathrm{M}^{+}, 89\right), 199$ (39), 155 (34), 128 (95), 77 (100). Anal. Calcd for $\mathrm{C}_{15} \mathrm{H}_{16} \mathrm{O}_{2}$ : C, 78.92; H, 7.06. Found: C, 78.41; H, 7.89.

3.1.9. 3-Methyl-2,3,4,5-tetrahydro-cyclopenta[a]naphthalen-1-one (4a). Typical procedure. To a solution of 3a $(180 \mathrm{mg}, 0.80 \mathrm{mmol})$ in anhydrous DCM $(7 \mathrm{~mL})$ under argon atmosphere, Amberlyst- $15^{\circledR}$ ( 2.3 mequiv/g, $18 \mathrm{mg}$ ) was added and the resulting mixture was stirred at $25{ }^{\circ} \mathrm{C}$. The reaction was monitored by TLC: after $2 \mathrm{~h}$ the resin was filtered off through a short pad of $\mathrm{K}_{2} \mathrm{CO}_{3}$ and concentrated under vacuum. Crude products were purified by flash chromatography (petroleum ether- $\mathrm{Et}_{2} \mathrm{O} 1: 1,0.5 \%$ $\left.\mathrm{Et}_{3} \mathrm{~N}, R_{\mathrm{f}} 0.4\right)$ to give pure $4 \mathrm{a}(110 \mathrm{mg}, 69 \%) .{ }^{1} \mathrm{H} \mathrm{NMR}$ $\left(\mathrm{CDCl}_{3}, 400 \mathrm{MHz}\right): \delta 8.21(\mathrm{~d}, J=6.2 \mathrm{~Hz}, 1 \mathrm{H}), 7.24(\mathrm{~m}, 3 \mathrm{H})$, 2.95 (br s, 3H), 2.81 (dd, $J=19.4,5.5 \mathrm{~Hz}, 1 \mathrm{H}), 2.69(\mathrm{~m}$, $1 \mathrm{H}), 2.58(\mathrm{~m}, 1 \mathrm{H}), 2.16(\mathrm{~d}, J=19.4 \mathrm{~Hz}, 1 \mathrm{H}), 1.35$ (d, $J=$ $6.5 \mathrm{~Hz}, 3 \mathrm{H}) ;{ }^{13} \mathrm{C} \mathrm{NMR}\left(\mathrm{CDCl}_{3}, 100 \mathrm{MHz}\right) \delta 205.60,178.91$, $134.46,134.17,129.21,127.90,127.57,126.85,124.26$, 44.85, 35.39, 27.79, 24.80, 18.74; MS m/z $198\left(\mathrm{M}^{+}, 100\right)$, 183 (42), 170 (53), 155 (60). Anal. Calcd for $\mathrm{C}_{14} \mathrm{H}_{14} \mathrm{O}$ : C, 84.81; H, 7.12. Found: C, 84.21; H, 7.88.

3.1.10. 3,5-Dimethyl-2,3,4,5-tetrahydro-cyclopenta[a]naphthalen-1-one (4b). Flash chromatography $\left(\mathrm{Et}_{2} \mathrm{O}-\right.$ petroleum ether $\left.1: 1,0.5 \% \mathrm{Et}_{3} \mathrm{~N}\right)$ gave pure $4 \mathbf{b}$ as $1: 1$ mixture of diastereoisomers. $\left(110 \mathrm{mg}, 63 \%, R_{\mathrm{f}}=0.35\right)$ as a colorless oil. ${ }^{1} \mathrm{H}$ NMR $\left(\mathrm{CDCl}_{3}, 400 \mathrm{MHz}\right): \delta 8.25(\mathrm{~d}$, 
$J=6.2 \mathrm{~Hz}, 2 \mathrm{H}$ cis + trans $), 7.23(\mathrm{~m}, 6 \mathrm{H}$, cis + trans $), 3.1(\mathrm{~m}$, $2 \mathrm{H}$, cis + trans $), 2.8(\mathrm{~m}, 2 \mathrm{H}$, cis + trans $), 2.82(\mathrm{dd}, J=17.9$, $5.1 \mathrm{~Hz}, 1 \mathrm{H}$ trans $), 2.80(\mathrm{dd}, J=18.3,7.5 \mathrm{~Hz}, 2 \mathrm{H} \mathrm{cis}+$ trans), 2.67 (dd, $J=17.9,5.0 \mathrm{~Hz}, 1 \mathrm{H}$ cis $), 2.48(\mathrm{dd}, J=17.9$, $6.6 \mathrm{~Hz}, 1 \mathrm{H} \mathrm{cis}$ ), 2.33 (dd, J=17.9, $6.0 \mathrm{~Hz}, 1 \mathrm{H}$ trans), 2.17 $(\mathrm{d}, J=18.3 \mathrm{~Hz}, 2 \mathrm{H}$, cis + trans $), 1.25(\mathrm{~d}, J=6.2 \mathrm{~Hz}, 3 \mathrm{H})$, $1.24(\mathrm{~d}, J=6.2 \mathrm{~Hz}, 3 \mathrm{H}), 1.23(\mathrm{~d}, J=6.2 \mathrm{~Hz}, 3 \mathrm{H}), 1.22(\mathrm{~d}$, $J=6.2 \mathrm{~Hz}, 3 \mathrm{H}) ;{ }^{13} \mathrm{C} \mathrm{NMR}\left(\mathrm{CDCl}_{3}, 100 \mathrm{MHz}\right): \delta 205.60$, $205.33,177.72,177.60,139.80,139.62,128.20,126.72$, 126.62, 126.32, 124.43, 44.90, 44.79, 32.74, 32.68, 32.60, 32.48, 21.68, 20.91, 19.26, 18.51; MS m/z $212\left(\mathrm{M}^{+}, 97\right)$, 197 (47), 184 (22), 155 (100). Anal. Calcd for $\mathrm{C}_{15} \mathrm{H}_{16} \mathrm{O}: \mathrm{C}$, 84.87; H, 7.60. Found: C, 84.21; H, 7.88.

3.1.11. 6-Methoxy-3-methyl-2,3,4,5-tetrahydro-cyclopenta $[a]$ naphthalen-1-one $(\mathbf{4 c})$. Flash chromatography $\left(\mathrm{Et}_{2} \mathrm{O}\right.$-petroleum ether $\left.3: 7,0.5 \% \quad \mathrm{Et}_{3} \mathrm{~N}\right)$ gave pure $4 \mathrm{c}$ $\left(120 \mathrm{mg}, 53 \%, R_{\mathrm{f}}=0.4\right)$ as a colorless oil. ${ }^{1} \mathrm{H}$ NMR $\left(\mathrm{CDCl}_{3}, 200 \mathrm{MHz}\right): \delta 8.21(\mathrm{~d}, J=5.5 \mathrm{~Hz}, 1 \mathrm{H}), 7.24(\mathrm{t}, J=$ $5.5 \mathrm{~Hz}, 1 \mathrm{H}), 6.85(\mathrm{~d}, J=5.5 \mathrm{~Hz}, 1 \mathrm{H}), 3.83(\mathrm{~s}, 3 \mathrm{H}), 2.95(\mathrm{~m}$, $3 \mathrm{H}), 2.78$ (dd, $J=19.4,5.5 \mathrm{~Hz}, 1 \mathrm{H}), 2.6(\mathrm{~m}, 2 \mathrm{H}), 2.15$ (d, $J=19.4 \mathrm{~Hz}, 1 \mathrm{H}), 1.35(\mathrm{~d}, J=6.5 \mathrm{~Hz}, 3 \mathrm{H}) ;{ }^{13} \mathrm{C} \mathrm{NMR}$ $\left(\mathrm{CDCl}_{3}, 50 \mathrm{MHz}\right) \delta 205.45,178.22,156.09,127.10$, $126.30,125.51,116.94,110.36,109.65,55.44,44.72$, 35.19, 24.16, 19.82, 15.22; MS m/z $228\left(\mathrm{M}^{+}, 100\right), 200$ (40), 185 (34), 115 (28). Anal. Calcd for $\mathrm{C}_{15} \mathrm{H}_{16} \mathrm{O}_{2}$ : C, 78.92; H, 7.06. Found: C, 78.25; H, 7.88.

3.1.12. 3-Methyl-2,3-dihydro-5H-cyclopenta[c]isochromen-1-one (4d). Flash chromatography $\left(\mathrm{Et}_{2} \mathrm{O}-\right.$ petroleum ether $\left.45: 55,0.5 \% \mathrm{Et}_{3} \mathrm{~N}\right)$ gave pure $4 \mathbf{d}(118 \mathrm{mg}$, $\left.59 \%, R_{\mathrm{f}}=0.4\right)$ as a colorless oil. ${ }^{1} \mathrm{H} \mathrm{NMR}\left(\mathrm{CDCl}_{3}\right.$, $200 \mathrm{MHz}): \delta 7.3(\mathrm{~m}, 4 \mathrm{H}), 5.32(\mathrm{~d}, J=8.5 \mathrm{~Hz}, 2 \mathrm{H}), 3.28$ (m, 1H), 2.78 (dd, $J=19.3,5.5 \mathrm{~Hz}, 1 \mathrm{H}), 2.18$ (d, $J=$ $19.4 \mathrm{~Hz}, 1 \mathrm{H}), 1.37(\mathrm{~d}, J=6.5 \mathrm{~Hz}, 3 \mathrm{H}) ;{ }^{13} \mathrm{C} \mathrm{NMR}\left(\mathrm{CDCl}_{3}\right.$, $100 \mathrm{MHz}) \delta 196.89,144.44,128.58,128.28,126.70$, $126.43,126.20,122.70,120.42,67.79,40.44,25.70$, 18.86; MS m/z $200\left(\mathrm{M}^{+}, 100\right), 200$ (40), 185 (32), 158 (21), 115 (56), 64 (25). Anal. Calcd for $\mathrm{C}_{13} \mathrm{H}_{12} \mathrm{O}_{2}$ : C, 77.98; H, 6.04. Found: C, 77.55; H, 6.04.

3.1.13. 1-(1H-Isochromen-3-yl)-but-2-en-1-one (5d). (40 mg, 20\%, $\left.R_{\mathrm{f}}=0.75\right)$ as a colorless oil. ${ }^{1} \mathrm{H}$ NMR $\left(\mathrm{CDCl}_{3}, 200 \mathrm{MHz}\right): \delta 7.2(\mathrm{~m}, 4 \mathrm{H}), 7.17(\mathrm{dq}, J=15.5$, $6.5 \mathrm{~Hz}, 1 \mathrm{H}), 7.05(\mathrm{~s}, 1 \mathrm{H}), 6.84(\mathrm{~d}, J=15.5 \mathrm{~Hz}, 1 \mathrm{H}), 5.19$ (s, $2 \mathrm{H}), 1.97(\mathrm{~d}, J=6.5 \mathrm{~Hz}, 3 \mathrm{H}) ;{ }^{13} \mathrm{C} \mathrm{NMR}\left(\mathrm{CDCl}_{3}, 50 \mathrm{MHz}\right) \delta$ $185.14,151.59,145.00,129.96,129.65,129.35,128.68$, 125.96, 125.84, 124.24, 111.96, 68.94, 18.77; MS m/z 200 $\left(\mathrm{M}^{+}, 23\right), 103$ (26), 77(17), 69 (100). Anal. Calcd for $\mathrm{C}_{13} \mathrm{H}_{12} \mathrm{O}_{2}$ : C, 77.98; H, 6.04. Found: C, 77.15; H, 6.84.

\subsection{General procedure for the arylation of ethoxydienes $(\mathbf{6 a}-\mathbf{c})$}

Ethoxydiene ( $2 \mathrm{mmol}$ ) was added to a mixture of the corresponding arendiazonium tetrafluoborate $(1 \mathrm{mmol})$, $\mathrm{Pd}(\mathrm{OAc})_{2}(0.05 \mathrm{mmol}), \mathrm{K}_{2} \mathrm{CO}_{3}$ or $\mathrm{NaOAc}(1 \mathrm{mmol})$ in anhydrous $\mathrm{CH}_{3} \mathrm{CN}$ (6 mL) degassed with argon for $10 \mathrm{~min}$. The reaction mixture was stirred under argon in a sealed tube for 15-30 min. Samples were periodically taken and tested with $\beta$-naphtol. After complete consumption of the starting tetrafluoborate, $\mathrm{H}_{2} \mathrm{O}(10 \mathrm{~mL})$ was added. All reactions were worked up by extraction with $\mathrm{Et}_{2} \mathrm{O}(3 \times$
$20 \mathrm{~mL})$ and the organic phases were washed with brine $(3 \times$ $10 \mathrm{~mL})$. The products were purified by column chromatography on $\mathrm{SiO}_{2}$ deactivated with $1 \%$ of $\mathrm{Et}_{3} \mathrm{~N}$. Eluent: petroleum ether/ $\mathrm{Et}_{2} \mathrm{O}$.

3.2.1. (E)-2-[03-(4-Methoxyphenyl)prop-1-enyl]-1,3dioxane (7a). $70 \mathrm{mg},(30 \%)$ as a colorless oil (70/30). ${ }^{1} \mathrm{H}$ NMR $\left(200 \mathrm{MHz}, \mathrm{CDCl}_{3}\right) \delta 7.02(\mathrm{~d}, J=8.6 \mathrm{~Hz}, 2 \mathrm{H}), 6.75(\mathrm{~d}$, $J=8.6 \mathrm{~Hz}, 2 \mathrm{H}), 5.97(\mathrm{dt}, J=16.4,6.9 \mathrm{~Hz}, 1 \mathrm{H}), 5.42$ (ddt, $J=16.4,5.2,1.5 \mathrm{~Hz}, 1 \mathrm{H}), 4.95(\mathrm{~d}, J=5.2 \mathrm{~Hz}, 1 \mathrm{H}), 4.05(\mathrm{~m}$, 2H), $3.77(\mathrm{~m}, 5 \mathrm{H}), 3.28(\mathrm{~d}, J=6.9 \mathrm{~Hz}, 2 \mathrm{H}), 2.0(\mathrm{~m}, 1 \mathrm{H}), 1.3$ $(\mathrm{m}, 1 \mathrm{H}) ;{ }^{13} \mathrm{C} \mathrm{NMR}\left(50 \mathrm{MHz}, \mathrm{CDCl}_{3}\right) \delta 158.01,134.48$, 129.66, 127.94, 113.84, 100.86, 66.88, 55.23, 34.48, 25.64; $\mathrm{m} / \mathrm{z}$ (EI, $70 \mathrm{eV}$ rel. Int.) $234\left(\mathrm{M}^{+}, 38\right), 147$ (37), 113 (100), 87 (92), 55 (31). $\nu_{\max }$ (neat) $/ \mathrm{cm}^{-1} 3050,1650,1635,1251$, 823, 808. (Found: C, 71.00\%; H 7.93\%. Calcd for $\mathrm{C}_{14} \mathrm{H}_{18} \mathrm{O}_{3}$ : C, 71.77\%; H, 7.74\%).

3.2.2. (E)-2-[3-(3-Methoxyphenyl)prop-1-enyl]-1,3-dioxane (7b). $86 \mathrm{mg},\left(37 \%\right.$ yield) as a colorless oil (70/30). ${ }^{1} \mathrm{H}$ NMR $\left(200 \mathrm{MHz}, \mathrm{CDCl}_{3}\right) \delta 7.2(\mathrm{~m}, 2 \mathrm{H}), 6.7(\mathrm{~m}, 2 \mathrm{H}), 6.05$ $(\mathrm{dt}, J=16.0,6.6 \mathrm{~Hz}, 1 \mathrm{H}), 5.55(\mathrm{dm}, J=16.0 \mathrm{~Hz}, 1 \mathrm{H}), 4.95$ $(\mathrm{d}, J=5.6 \mathrm{~Hz}, 1 \mathrm{H}), 4.10(\mathrm{~m}, 2 \mathrm{H}), 3.80(\mathrm{~m}, 5 \mathrm{H}), 3.38(\mathrm{~d}, J=$ $6.6 \mathrm{~Hz}, 2 \mathrm{H}), 1.5(\mathrm{~m}, 2 \mathrm{H}) ;{ }^{13} \mathrm{C} \mathrm{NMR}\left(50 \mathrm{MHz}, \mathrm{CDCl}_{3}\right) \delta$ $159.70,140.89$, 133.83, 129.38, 128.33, 121.12, 114.40, $111.58,100.78,66.90,55.14,38.44,25.67 ; \mathrm{m} / \mathrm{z}(\mathrm{EI}, 70 \mathrm{eV}$ rel. Int.) $234\left(\mathrm{M}^{+}, 21\right), 158(38), 147$ (17), 113 (100), 83 (23). $\nu_{\max }$ (neat) $/ \mathrm{cm}^{-1} 3010,2853,1599,1454,1259,1078$, 993, 773. (Found: C, 71.90\%; H 7.02\%. Calcd for $\mathrm{C}_{14} \mathrm{H}_{18} \mathrm{O}_{3}$ : C, 71.77\%; H, 7.74\%).

3.2.3. (E)-2-[3-(4-Iodophenyl)prop-1-enyl]-1,3-dioxane (7c). $112 \mathrm{mg}$, (34\% yield) as a colorless oil (70/30). ${ }^{1} \mathrm{H}$ NMR (200 MHz, $\left.\mathrm{CDCl}_{3}\right) \delta 7.65(\mathrm{~d}, J=7.4 \mathrm{~Hz}, 2 \mathrm{H}), 6.95(\mathrm{~d}$, $J=7.4 \mathrm{~Hz}, 2 \mathrm{H}), 6.05(\mathrm{dt}, J=15.4,6.2 \mathrm{~Hz}, 1 \mathrm{H}), 5.50(\mathrm{dbd}$, $J=15.4,6.2 \mathrm{~Hz}, 1 \mathrm{H}), 4.95(\mathrm{~d}, J=6.2 \mathrm{~Hz}, 1 \mathrm{H}), 4.15(\mathrm{~m}, 2 \mathrm{H})$, $3.80(\mathrm{~m}, 2 \mathrm{H}), 3.30(\mathrm{~d}, J=6.5 \mathrm{~Hz}, 2 \mathrm{H}), 2.1(\mathrm{~m}, 1 \mathrm{H}), 1.3(\mathrm{~m}$, $1 \mathrm{H}) ;{ }^{13} \mathrm{C} \mathrm{NMR}\left(50 \mathrm{MHz}, \mathrm{CDCl}_{3}\right) \delta 139.20,137.42,133.12$, $130.79,128.73,100.53,91.30,66.85,37.77,25.61 ; \mathrm{m} / \mathrm{z}(\mathrm{EI}$, $70 \mathrm{eV}$ rel. Int.) $330\left(\mathrm{M}^{+}, 5\right), 144$ (15), $113(100), 100(36)$, 55 (29). $\nu_{\max }$ (neat) $/ \mathrm{cm}^{-1} 3050,2851,1279,1078,930,800$. (Found: C, 47.85\%; H 4.99\%. Calcd for $\mathrm{C}_{13} \mathrm{H}_{15} \mathrm{IO}_{2}: \mathrm{C}$, $47.29 \%$; H, $4.58 \%$ ).

3.2.4. (E)-2-[3-(4-Chlorophenyl)prop-1-enyl]-1,3-dioxane (7d). $81 \mathrm{mg},\left(34 \%\right.$ yield) as a colorless oil $(90 / 10) .{ }^{1} \mathrm{H}$ NMR $\left(200 \mathrm{MHz}, \mathrm{CDCl}_{3}\right) \delta 7.25(\mathrm{~d}, J=7.0 \mathrm{~Hz}, 2 \mathrm{H}), 7.05(\mathrm{~d}$, $J=7.0 \mathrm{~Hz}, 2 \mathrm{H}), 6.20(\mathrm{dt}, J=14.9,6.0 \mathrm{~Hz}, 1 \mathrm{H}), 5.55(\mathrm{dbd}$, $J=14.9,5.8 \mathrm{~Hz}, 1 \mathrm{H}), 4.95(\mathrm{~d}, J=5.8 \mathrm{~Hz}, 1 \mathrm{H}), 4.15(\mathrm{~m}, 2 \mathrm{H})$, $3.85(\mathrm{~m}, 2 \mathrm{H}), 3.35(\mathrm{~d}, J=6.0 \mathrm{~Hz}, 2 \mathrm{H}), 1.6(\mathrm{~m}, 1 \mathrm{H}), 1.3(\mathrm{~m}$, $1 \mathrm{H}) ;{ }^{13} \mathrm{C} \mathrm{NMR}\left(50 \mathrm{MHz}, \mathrm{CDCl}_{3}\right) \delta 133.33,132.05,130.06$, $129.50,128.67,128.51,100.55,66.88,37.65,25.61 ; \mathrm{m} / \mathrm{z}$ (EI, 70 eV rel. Int.) $238\left(\mathrm{M}^{+}, 56\right), 180$ (46), 145 (100), 115 (50), 68 (40), 55 (50). $\nu_{\max }$ (neat)/cm ${ }^{-1} 3080,1599,1259$, 1078, 993, 773. (Found: C, 66.05\%; H 6.65\%. Calcd for $\mathrm{C}_{13} \mathrm{H}_{15} \mathrm{ClO}_{2}$ : C, 65.41\%; H, 6.33\%).

3.2.5. (E)-2-[3-(4-Iodophenyl)-2-methylprop-1-enyl)-5,5dimethyl-1,3-dioxane (7e). $100 \mathrm{mg},(27 \%$ yield) as a colorless oil (90/10). ${ }^{1} \mathrm{H}$ NMR $\left(200 \mathrm{MHz}, \mathrm{CDCl}_{3}\right) \delta 7.62$ $(\mathrm{d}, J=8.0 \mathrm{~Hz}, 2 \mathrm{H}), 6.94(\mathrm{~d}, J=8.0 \mathrm{~Hz}, 2 \mathrm{H}), 5.11(\mathrm{bd}, J=$ $6.3 \mathrm{~Hz}, 1 \mathrm{H}), 5.08(\mathrm{~d}, J=6.3 \mathrm{~Hz}, 1 \mathrm{H}), 3.65(\mathrm{~m}, 2 \mathrm{H}), 3.51(\mathrm{~m}$, $2 \mathrm{H}), 3.23$ (s, 2H), $1.68(\mathrm{~s}, 3 \mathrm{H}), 1.23(\mathrm{~s}, 3 \mathrm{H}), 0.75(\mathrm{~s}, 3 \mathrm{H}) ;{ }^{13} \mathrm{C}$ 
NMR $\left(50 \mathrm{MHz}, \mathrm{CDCl}_{3}\right) \delta 141.44,139.31,138.42,137.98$, $137.41,131.23,124.27,98.75,45.12,30.02,22.97,21.95$, 17.03; $\mathrm{m} / \mathrm{z}$ (EI, $70 \mathrm{eV}$ rel. Int.) $372\left(\mathrm{M}^{+}, 3\right), 155$ (86), 128 (14), 115 (15), 69 (100). (Found: C, 49.20\%; H 5.15\%. Calcd for $\mathrm{C}_{14} \mathrm{H}_{17} \mathrm{IO}_{2}$ : C, $48.85 \%$; $\mathrm{H}, 4.98 \%$ ).

3.2.6. (E)-2-[3-(4-Chlorophenyl)-2-methylprop-1-enyl)1,3-dioxane (7f). $63 \mathrm{mg}$, (25\% yield) as a colorless oil (90/10). ${ }^{1} \mathrm{H}$ NMR $\left(200 \mathrm{MHz}, \mathrm{CDCl}_{3}\right) \delta 7.35(\mathrm{~d}, J=8.6 \mathrm{~Hz}$, $2 \mathrm{H}), 7.05(\mathrm{~d}, J=8.6 \mathrm{~Hz}, 2 \mathrm{H}), 5.25(\mathrm{~d}, J=6.2 \mathrm{~Hz}, 1 \mathrm{H}), 5.15$ $(\mathrm{d}, J=6.2 \mathrm{~Hz}, 1 \mathrm{H}), 4.15(\mathrm{~m}, 2 \mathrm{H}), 3.80(\mathrm{~m}, 2 \mathrm{H}), 3.25(\mathrm{~s}, 2 \mathrm{H})$, $2.3(\mathrm{~m}, 1 \mathrm{H}), 1.65(\mathrm{~s}, 3 \mathrm{H}), 1.2(\mathrm{~m}, 1 \mathrm{H}) ;{ }^{13} \mathrm{C} \mathrm{NMR}(50 \mathrm{MHz}$, $\left.\mathrm{CDCl}_{3}\right) \delta 141.25,137.16,130.42,128.42,124.53,98.75$, 66.90, 44.88, 25.58, 16.98; $\mathrm{m} / \mathrm{z}$ (EI, $70 \mathrm{eV}$ rel. Int.) 252 $\left(\mathrm{M}^{+}, 2\right), 127$ (100), 87 (13), 69 (42), 41 (16). $\nu_{\max }$ (neat)/ $\mathrm{cm}^{-1} 3050,1490,1376,1138,1086,994,787$. (Found: C, $67.00 \% ; \mathrm{H} \mathrm{7.10 \%}$. Calcd for $\mathrm{C}_{14} \mathrm{H}_{17} \mathrm{ClO}_{2}$ : C, 66.53\%; $\mathrm{H}$, $6.78 \%)$

3.2.7. (E)-2-[3-(4-Iodophenyl)-1-methylprop-1-enyl)-1,3dioxane (7g). $103 \mathrm{mg}$, (30\% yield) as a colorless oil (90/10). ${ }^{1} \mathrm{H}$ NMR $\left(200 \mathrm{MHz} \mathrm{CDCl}_{3}\right) \delta 7.57(\mathrm{~d}, J=7.0 \mathrm{~Hz}, 2 \mathrm{H}), 6.95$ $(\mathrm{d}, J=7.0 \mathrm{~Hz}, 2 \mathrm{H}), 5.75(\mathrm{bt}, J=6.6 \mathrm{~Hz}, 1 \mathrm{H}), 4.82(\mathrm{~s}, 1 \mathrm{H})$, $4.10(\mathrm{~m}, 2 \mathrm{H}), 3.82(\mathrm{~m}, 2 \mathrm{H}), 3.15(\mathrm{~d}, J=6.8 \mathrm{~Hz}, 2 \mathrm{H}), 2.1(\mathrm{~m}$, $1 \mathrm{H}), 1.80(\mathrm{~s}, 3 \mathrm{H}), 1.1(\mathrm{~m}, 1 \mathrm{H}) ;{ }^{13} \mathrm{C} \mathrm{NMR}\left(50 \mathrm{MHz}, \mathrm{CDCl}_{3}\right)$ $\delta$ 137.89, 137.42, 130.54, 126.99, 104.50, 91.00, 67.02, 33.14, 25.72, 15.00; $\mathrm{m} / \mathrm{z}$ (EI, $70 \mathrm{eV}$ rel. Int.) $344\left(\mathrm{M}^{+}, 7\right)$, 127 (100), 87 (57), 69 (33), 59 (15). $\nu_{\max }$ (neat) $/ \mathrm{cm}^{-1} 3050$, 1483, 1377, 1151, 1107, 958, 801. (Found: C, 49.15\%; H $4.75 \%$. Calcd for $\mathrm{C}_{14} \mathrm{H}_{17} \mathrm{IO}_{2}: \mathrm{C}, 48.85 \% ; \mathrm{H}, 4.98 \%$ ).

3.2.8. (E)-1-(4-Methoxyphenyl)-ott-2-en-4-one (8). $50 \mathrm{mg}$, (22\% yield) as a colorless oil (90/10). ${ }^{1} \mathrm{H}$ NMR $\left(200 \mathrm{MHz}, \mathrm{CDCl}_{3}\right) \delta 7.02(\mathrm{~d}, J=7.2 \mathrm{~Hz}, 2 \mathrm{H}), 6.9(\mathrm{~m}, 3 \mathrm{H})$, $6.05(\mathrm{bd}, J=15.0 \mathrm{~Hz}, 1 \mathrm{H}), 3.80(\mathrm{~s}, 3 \mathrm{H}), 3.45(\mathrm{bd}, J=$ $6.2 \mathrm{~Hz}, 2 \mathrm{H}), 2.55(\mathrm{t}, J=6.1 \mathrm{~Hz}, 2 \mathrm{H}), 1.55$ (pent, $J=6.0 \mathrm{~Hz}$, $2 \mathrm{H}), 1.32$ (sext, $J=6.0 \mathrm{~Hz}, 2 \mathrm{H}), 0.9(\mathrm{t}, J=6.0 \mathrm{~Hz}, 3 \mathrm{H}) ;{ }^{13} \mathrm{C}$ NMR $\left(50 \mathrm{MHz}, \mathrm{CDCl}_{3}\right) \delta 200.66,158.32,145.40,130.76$, 129.66, 114.00, 55.14, 39.71, 37.74, 26.17, 22.28, 13.76; $\mathrm{m} / \mathrm{z}$ (EI, $70 \mathrm{eV}$ rel. Int.) $232\left(\mathrm{M}^{+}, 66\right), 160$ (44), 175 (34), 147 (100), 121 (29). $\nu_{\max }$ (neat)/cm ${ }^{-1} 3030,1672,1626$, 1458, 1246, 1033, 733. (Found: C, 78.05\%; H 8.20\%. Calcd for $\mathrm{C}_{15} \mathrm{H}_{20} \mathrm{O}_{2}$ : C, $77.55 \% ; \mathrm{H}, 8.68 \%$ ).

\section{Acknowledgements}

Authors thank the Università degli Studi di Torino and the Italian MIUR for financial support through the 'Cofinanziamento di Programmi di Ricerca di Rilevante Interesse Nazionale'.

\section{References and notes}

1. Schlosser, M. J. Organomet. Chem. 1967, 8, 9-16. Schlosser, M. Mod. Synth. Methods 1992, 6, 227-271. Mordini, A. In Snieckus, V., Ed.; Advances in Carbanion Chemistry; JAI: Greenwich, CT, 1992; Vol. 1, pp 1-45. Schlosser, M.; Faigl, F.; Franzini, L.; Geneste, H.; Katsoulos, G.; Zhong, G. Pure
Appl. Chem. 1994, 66, 1439-1446. Lochmann, L. Eur. J. Inorg. Chem. 2000, 1115-1126.

2. Venturello, P. J. Chem. Soc., Chem. Commun. 1992, 1032-1033.

3. Prandi, C.; Venturello, P. J. Org. Chem. 1994, 59, 3494-3496. (and 5458-5462)

4. Balma Tivola, P.; Deagostino, A.; Prandi, C.; Venturello, P. J. Chem. Soc., Perkin Trans. 1 2001, 437-441. Deagostino, A.; Prandi, C.; Venturello, P. Curr. Org. Chem. 2003, 7, 821-839.

5. Balma Tivola, P.; Deagostino, A.; Prandi, C.; Venturello, P. Chem. Commun. 2001, 1536-1537. Deagostino, A.; Prandi, C.; Zavattaro, C.; Venturello, P. Eur. J. Org. Chem. 2003, 2612-2616.

6. Balma Tivola, P.; Deagostino, A.; Prandi, C.; Venturello, P. Org. Lett. 2002, 4, 1275-1277.

7. Deagostino, A.; Prandi, C.; Venturello, P. Org. Lett. 2003, 5, 3815-3817.

8. Occhiato, E. G.; Prandi, C.; Ferrali, A.; Guarna, A.; Deagostino, A.; Venturello, P. J. Org. Chem. 2002, 67, 7144-7146. Occhiato, E. G.; Prandi, C.; Ferrali, A.; Guarna, A.; Venturello, P. J. Org. Chem. 2003, 68, 9728-9741. Prandi, C.; Ferrali, A.; Guarna, A.; Venturello, P.; Occhiato, E. G. J. Org. Chem. 2004, 69, 0000.

9. Nazarov, I. N.; Torgov, I. B.; Terekhova, L. N. Izv. Akad. Nauk SSSR, Otd. Khim. Nauk 1942, 200. Braude, E. A.; Forbes, W. F. J. Chem. Soc. 1953, 2208-2216. Habermas, K. L.; Denmark, S. E.; Jones, T. D. Org. React. 1994, 45, 1-158. Denmark, S. E. In Trost, B. M., Fleming, I., Eds.; Comprehensive Organic Synthesis; Pergamon: Oxford, UK, 1991; Vol. 5, pp 751-784. Harrington, P. E.; Tius, M. A. J. Am. Chem. Soc. 2001, 123, 8509-8514 and references therein.

10. Denmark, S. E.; Habernas, K. L.; Hite, G. A.; Jones, T. K. Tetrahedron 1986, 42, 2821-2829.

11. Nicolaou, K. C.; Gray, D. L. F. J. Am. Chem. Soc. 2004, 126, 607-612 and references therein.

12. Wellington, K.; Cambie, R.; Rutledge, P.; Bergquist, P. J. Nat. Prod. 2000, 63, 79-85.

13. Shinde, H. M. Tetrahedron Lett. 2003, 44, 7049-7053.

14. Cambie, R.; Lai, A.; Kernan, M. J. Nat. Prod. 1993, 58, 940-942. Cambie, R. C.; Richard, C. E. F.; Rutledge, P. S.; Wellington, K. D. Acta Crystallogr. 2001, C57, 958-960.

15. Clive, D. L. J.; Wang, J. Tetrahedron Lett. 2003, 44, 7731-7733. Nicolaou, K. C.; Gray, D. L. F. J. Am. Chem. Soc. 2004, 126, 613-627.

16. Baker, R.; Bradshaw, J. W. S. In Aliphatic and Related Natural Product Chemistry; Gunstone, F. D., Ed.; Royal Society of Chemistry: London, 1983. Nicolaou, K. C.; Ramphal, J. Y.; Petasis, N. A.; Serhan, C. N. Angew. Chem., Int. Ed. Engl. 1991, 30, 1100-1116. Launay, V.; Beaude, I.; Quintard, J.-P. Bull. Soc. Chim. Fr. 1997, 134, 937-946. Dominguez, B.; Iglesia, B.; de Lera, A. R. J. Org. Chem. 1998, 63, 4135-4139. Lipshutz, B. H.; Ullman, B.; Lindsley, C.; Pecchi, S.; Buzard, D. J.; Dickson, D. J. Org. Chem. 1998, 63, 6092-6093. Peng, Z. H.; Li, Y. L.; Wu, W. L.; Liu, C. X.; Wu, Y. L. J. Chem. Soc., Perkin Trans. 1. 1996, 1057-1066. Chem. Rev. 1994, 94, 1-278. Becher, J., Schaumburg, K., Eds.; Molecular Engineering for Advanced Materials; Kluwer Academic: Dordrecht, 1995; Vol. 456, Specialist Periodical Report, Vol. 3, p 159.

17. Heck, R. F., Trost, B. M., Fleming, I., Eds.; Comprehensive Organic Synthesis; Pergamon: Oxford, 1991; Vol. 4, p 833.

18. Daves, G. D., Jr.; Hallberg, A. Chem. Rev. 1989, 89, 1433-1446. Andersson, C.-M.; Hallberg, A.; Daves, G. D., Jr. J. Org. Chem. 1987, 52, 3529-3536. Hegedus, L. S.; Toro, 
J. L.; Miles, W. H.; Harrington, P. J. J. Org. Chem. 1987, 52, 3319-3322.

19. Cabri, W.; Candiani, I.; Bedeschi, A.; Penco, S.; Santi, R. J. Org. Chem. 1992, 57, 1481-1486. Cabri, W.; Candiani, I.; Bedeschi, A.; Santi, R. J. Org. Chem. 1990, 55, 3654-3655. Andersson, C.-M.; Halberg, A. J. Org. Chem. 1989, 54, 1502-1505.

20. Cabri, W.; Candiani, I. Acc. Chem. Res. 1995, 28, $2-7$.

21. Andersson, C.-M.; Larsson, J.; Hallberg, A. J. Org. Chem. 1990, 55, 5757-5761. Larhed, M.; Andersson, C.-M.; Hallberg, A. Acta Chem. Scand. 1993, 47, 212-217.

22. Heck, R. F. Palladium Reagents in Organic Synthesis; Academic: London, 1985.

23. Beller, M.; Kühlein, K. Synlett 1995, 441-442.

24. Heck, R. F. Org. React. 1982, 27, 345-391. Ben-David, Y.;
Portnoy, M.; Gozin, M.; Milstein, D. Organometallics 1992, 11, 1995-1996.

25. Kikukawa, K.; Nagira, K.; Wada, F.; Matsuda, T. J. Chem. Soc., Perkin Trans. 1 1986, 1959-1964. Sengupta, S.; Bhattacharyya, S. J. Chem. Soc., Perkin Trans. 1 1993, 1943-1944.

26. Brunner, H.; Le Cousturier de Courcy, N.; Genêt, J.-P. Tetrahedron Lett. 1999, 40, 4815-4818.

27. Turksov, F.; Hughes, G.; Batsanov, A. S.; Bryce, M. R. J. Mater. Chem. 2003, 13, 1554-1557. Chapman, G. M.; Stanforth, S. P.; Tarbit, B.; Watson, M. D. J. Chem. Soc. Perkin Trans. 1 2002, 581-582. Goel, A.; Srivastava, P.; Nath, M.; Ram, V. J. Synthesis 1998, 167-170.

28. Roe, A. Org. React. 1949, 5, 193-227. 